\title{
Potensi antibakteri dari susu fermentasi dengan starter Lactobacillus casei terhadap Escherichia coli dan Staphylococcus aureus
}

\author{
Danu Purnomo ${ }^{1, *}$, Pratiwi Apridamayanti ${ }^{1}$, Rafika Sari ${ }^{1}$

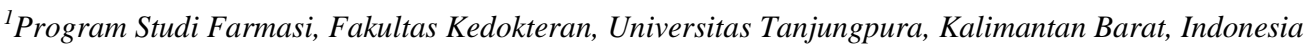 \\ *Korespondensi: danu.purnomo@student.untan.ac.id
}

\begin{abstract}
Abstrak
Latar belakang: Susu fermentasi merupakan bahan pangan dari susu yang dibuat dengan fermentasi bakteri asam laktat. Bakteri asam laktat seperti Lactobacillus casei dalam susu fermentasi memiliki manfaat dalam kesehatan terutama mengatasi gangguan saluran pencernaan yang disebabkan oleh bakteri patogen seperti Escherichia coli dan Staphylococcus aureus. Bakteri patogen tersebut dapat dihambat dengan adanya senyawa antibakteri yang dihasilkan dari bakteri asam laktat yaitu bakteriosin yang memiliki efek antibakteri spektrum luas. Bakteriosin oleh Lactobacillus casei diproduksi optimum pada waktu 24 dan 48 jam sehingga perlu dilakukan perbandingan aktivitas antibakteri bakteriosin yang lebih optimal antara waktu fermentasi 24 jam dan 48 jam pada bakteri E. coli dan S. aureus. Metode: Penelitian ini menggunakan metode difusi cakram dengan menggunakan sampel supernatan bakteriosin yang dibuat dengan teknik sentrifugasi. Hasil: Aktivitas antibakteri bakteriosin pada waktu fermentasi 24 jam memiliki aktivitas yang lebih besar daripada waktu fermentasi 48 jam. Diameter zona bening aktivitas bakteriosin yang dihasilkan terhadap bakteri E. coli dan $S$. aureus pada waktu fermentasi 24 jam yaitu 8,45 mm dan 9,32 mm sedangkan dengan waktu fermentasi 48 jam yaitu 6,77 mm dan 7,82 mm. Kesimpulan: Aktivitas antibakteri bakteriosin pada susu fermentasi yang dihasilkan oleh Lactobacillus casei lebih optimum pada waktu fermentasi 24 jam terhadap E. coli dan S. aureus.
\end{abstract}

Kata kunci: fermentasi, bakteriosin, Escherichia coli, Staphylococcus aureus, Lactobacillus casei, spektrum luas

\section{Antibacterial potential of fermented milk with Lactobacillus casei starter on Escherichia coli and Staphylococcus aureus}

\begin{abstract}
Background: Fermented milk is made from milk through fermentation by lactic acid bacteria. Lactic acid bacteria such as Lactobacillus casei in fermented milk have health benefits, especially in treating digestive tract disorders caused by pathogenic bacteria such as Escherichia coli and Staphylococcus aureus. These pathogenic bacteria can be inhibited by bacteriocins, antibacterial compounds produced by lactic acid bacteria with broad-spectrum antibacterial effects. Bacteriocins were produced optimally after 24 and 48 hours of fermentation, so it is necessary to compare the optimal antibacterial activity between 24 and 48 hours of fermentation against $E$. coli and S. aureus. Methods: This study used the disc diffusion method using bacteriocin supernatant prepared by centrifugation. Results: Antibacterial activity of bacteriocins at 24-hour fermentation time was greater than at 48-hour fermentation time. The diameters of the clear zone were $8.45 \mathrm{~mm}$ and $9.32 \mathrm{~mm}$ at 24-hour fermentation time and $6.77 \mathrm{~mm}$ and $7.82 \mathrm{~mm}$ at 48-hour fermentation time. Conclusions: The antibacterial activity of bacteriocins produced by Lactobacillus casei in fermented milk against $E$. coli and $S$. aureus is more optimum at the 24-hour fermentation time.
\end{abstract}

Keywords: fermentation, bacteriocin, Escherichia coli, Staphylococcus aureus, Lactobacillus casei, broad spectrum 


\section{Pendahuluan}

Susu fermentasi merupakan suatu produk susu bermanfaat untuk kesehatan. Susu fermentasi memiliki manfaat dalam mengatasi saluran pencernaan karena mengandung bakteri asam laktat yang aman untuk pencernaan. Contoh bakteri asam laktat yaitu Lactobacillus casei. ${ }^{1}$

Lactobacillus casei merupakan suatu bakteri asam laktat yang bersifat probiotik yang penting dalam proses fermentasi menghasilkan asam laktat $90 \%$, bakteriosin dan asam organik lainnya. ${ }^{2}$ Bakteriosin merupakan suatu senyawa protein yang bersifat antimikroba yang dapat dihasilkan oleh Lactobacillus casei. ${ }^{3}$ Mekanisme kerja bakteriosin pada umumnya ialah dengan menghancurkan target membran sitoplasma sel bakteri. ${ }^{4}$ Optimasi bakteriosin tertinggi yang dihasilkan oleh bakteri asam laktat terjadi dengan waktu fermentasi selama 24 dan 48 jam. ${ }^{5}$ sehingga pada susu fermentasi dengan starter Lactobacillus casei yang dibuat difermentasikan dengan waktu fermentasi selama 24 jam dan 48 jam untuk melihat potensi aktivitas bakteriosin yang optimum sebagai agen antimikroba dengan salah satu metode antimikroba yaitu metode difusi yaitu cara cakram.

Penelitian ini akan menggunakan metode difusi dengan cara cakram. Metode difusi bermanfaat dalam menguji kemampuan bertahan bakteri uji terhadap kadar agen antimikroba yang terdapat di cakram. Agen antimikroba yang digunakan pada penelitian ini adalah supernatan netral dari susu fermentasi dengan waktu fermentasi selama 24 jam dan 48 jam dan bakteri yang akan diujikan adalah Escherichia coli dan Staphylococcus aureus. Besar atau kecil zona bening yang terbentuk menunjukkan bahwa susu fermentasi memiliki aktivitas pada bakteri Escherichia coli serta Staphylococcus aureus dan membandingkan potensi aktivitas antibakteri minuman susu fermentasi dengan waktu fermentasi 24 dan 48 jam. Parameter yang dilihat dan diukur dari penelitian ini adalah diameter zona bening yang terbentuk menunjukkan kemampuan aktivitas antibakteri pada susu fermentasi 24 jam dan 48 jam.

\section{Metode}

\section{Bahan dan alat}

Bahan-bahan yang diperlukan yaitu susu sapi murni, susu skim, media MHA (Mueller Hinton
Agar), media MRSA (deMan Rogosa Sharpe Agar), media MRSB (deMan Rogosa Sharpe Broth), dan Kultur bakteri Lactobacillus casei di Laboratorium Biologi Fakultas Farmasi Universitas Tanjungpura.

Alat-alat yang diperlukan yaitu inkubator, autoklaf, LAF, kertas cakram, mikrosentrifus temperatur, ependorf, filter bakteri $0,22 \mathrm{um}$, vial, botol kaca, beaker kaca, mikropipet, hot plate, kertas merang.

\section{Pembuatan media}

Media MRSA dibuat dengan menimbang 2,4 gram lalu dilarutkan dalam $35 \mathrm{ml}$ akuades kemudian dipanaskan lalu dibungkus dengan kertas merang dan kemudian disterilisasi dengan alat autoklaf selama 15 menit saat temperatur mencapai $121^{\circ} \mathrm{C}$. Pembuatan Media MRS Broth dilakukan dengan melarutkan 1,57 gram bubuk MRS Broth dengan akuades sampai volumenya $30 \mathrm{ml}$. Media MRS Broth dipindahkan ke tabung reaksi sebanyak $7 \mathrm{ml}$ tiap tabung reaksi, kemudian disterilisasi dengan autoklaf mencapai temperatur $121^{\circ} \mathrm{C}$ selama 15 menit. $^{6}$

Media MHA dibuat dengan cara melarutkan 38 gram bubuk media Mueller Hinton Agar dalam 1000 $\mathrm{ml}$ akuades. Larutan dipanaskan dan diaduk menggunakan batang pengaduk sampai homogen. Media disterilisasi dengan menggunakan autoklaf selama 15 menit saat temperatur $121{ }^{\circ} \mathrm{C}$ lalu dimasukkan $10 \mathrm{ml}$ ke dalam cawan petri sebagai medium pengujian antibakteri. ${ }^{7}$

\section{Peremajaan bakteri starter}

Bakteri starter Lactobacillus casei diambil dari kultur stok dengan kawat ose lalu digoreskan di petri yang terdapat media MRSA kemudian diinkubasi dengan suhu $32^{\circ} \mathrm{C}$ selama 34 jam. Selanjutnya dipindahkan bakteri ke media agar miring lalu di inkubasi kembali di inkubator dengan suhu dan waktu yang sama. ${ }^{8}$ Inokulasikan Lactobacillus casei dari media agar miring ke $7 \mathrm{ml}$ media MRS Broth lalu diinkubasi dengan menggunakan inkubator yang diatur dengan suhu $32^{\circ} \mathrm{C}$ selama 24 jam. ${ }^{9}$

Media cair susu skim $10 \%$ (b/v) dibuat dengan ditimbang 10 gram bubuk susu skim lalu dilarutkan dalam $100 \mathrm{~mL}$ akuades dan glukosa 10 gram kemudian dipanaskan dan diaduk sampai larut sampai mencapai $85^{\circ} \mathrm{C}$ selama 10 menit. ${ }^{10}$ selanjutnya dibiarkan susu skim di suhu ruang sampai suhu $32^{\circ} \mathrm{C}$ lalu ditambahkan $5 \mathrm{ml}$ MRS Broth lalu diaduk sampai merata dan diinkubasi selama 24 
jam di inkubator dengan suhu $32{ }^{\circ} \mathrm{C}$.

\section{Pembuatan susu fermentasi}

Pembuatan susu fermentasi dilakukan dengan cara diambil susu sapi murni yang sudah dipasteurisasi kemudian ditambahkan $5 \mathrm{ml}$ susu skim $10 \%(\mathrm{~b} / \mathrm{v})$ lalu diaduk perlahan kemudian diinkubasi dengan suhu $32^{\circ} \mathrm{C}$ selama 24 jam dan 48 jam. Setelah susu fermentasi terbentuk maka susu fermentasi diaduk lalu disimpan di suhu dingin. ${ }^{11}$

\section{Uji aktivitas antibakteri}

Pengambilan supernatan netral susu fermentasi dilakukan dengan melakukan sentrifugasi menggunakan alat mikrosentrifus berpendingin dengan kecepatan 10000 rpm selama 10 menit lalu supernatan ditambahkan $\mathrm{NaOH} \quad 0,1 \quad \mathrm{~N}$ untuk mencapai $\mathrm{pH}$ 7,0. Supernatan netral kemudian disaring dengan bakteri filter diameter 0,22 um untuk pensterilan lalu dimasukkan ke dalam ependorf dan disimpan didalam lemari pendingin. ${ }^{12}$

Bakteri Escherichia coli dan Staphylococcus aureus masing-masing diambil koloni secukupnya yang sudah berusia 24 jam dengan kawat ose lalu disuspensikan dengan $0,9 \mathrm{ml} \mathrm{NaCl}$ fisiologis dan diinkubasi dengan suhu $37^{\circ} \mathrm{C}$ sehingga didapatkan kekeruhan. Suspensi bakteri yang telah dibuat kemudian disamakan tingkat kekeruhannya secara visualisasi dengan larutan standar yaitu Mc Farland III. $^{13}$

Uji aktivitas antibakteri pada susu fermentasi dapat dilakukan dengan metode difusi cakram dengan diinokulasikan masing-masing suspensi bakteri E. coli dan $S$.aureus yang akan digunakan ke permukaan media MHA lalu diletakkan kertas cakram yang sudah steril ke cawan petri disk ke media MHA. Sampel kemudian diteteskan $20 \mu \mathrm{L}$ ke kertas cakram steril lalu didiamkan selama 30 menit.
Masing-masing sampel kemudian diinkubasi selama 24 jam dengan temperature $37^{\circ} \mathrm{C}$. Diameter zona bening yang terbentuk kemudian diukur menggunakan jangka sorong. ${ }^{12,14}$

\section{Hasil}

Uji antibakteri susu fermentasi dilakukan untuk mengukur aktivitas antibakteri pada bakteriosin terhadap bakteri uji E. coli dan S. aureus. Metode yang digunakan adalah metode difusi cakram karena lebih mudah, dan sederhana. Uji antibakteri dilakukan dengan mensentrifugasi suhu dingin pada susu fermentasi 24 jam, 48 jam, serta kontrol positif yaitu yoguruto dan susu murni sebagai kontrol negatif. Menurut Angkuna 2019, tujuan dengan mensentrifugasi suhu dingin agar bakteriosin yang diinginkan tidak terdenaturasi oleh suhu tinggi dan proses sentrifugasi akan membuat dua lapisan yaitu supernatan dan filtrat. ${ }^{8}$ Bakteriosin dan asam-asam organik berada pada lapisan atas yaitu supernatan sedangkan pada lapisan bawah yaitu filtrat terdapat sisa komponen-komponen susu fermentasi dan sel-sel bakteri. Lapisan supernatan kemudian diberikan keadaan dingin untuk menjaga stabilitasnya lalu di filter dengan penyaring bakteri berukuran 0,22 um untuk pensterilan supernatan terhadap bebas sel bakteri. Kemudian supernatan ditambah $\mathrm{NaOH} 0,1 \mathrm{~N}$ sampai $\mathrm{pH}$ supernatan menjadi $\mathrm{pH}$ 7,0 dengan tujuan untuk menutup atau menghilangkan aktivitas asam-asam organik saat pengujian antibakteri sehingga didapatkan hanya aktivitas bakteriosin yang bekerja sebagai antibakteri. Kemudian supernatan netral disimpan di dalam lemari pendingin. supernatan netral diteteskan ke kertas cakram ukuran $6 \mathrm{~mm}$ di media lalu diinkubasi di inkubator dengan suhu $37^{\circ} \mathrm{C}$ selama 24 jam.

Tabel 1. Hasil uji antibakteri bakteriosin susu fermentasi terhadap bakteri Staphylococcus aureus dan Escherichia coli

\begin{tabular}{ccccccc}
\hline \multicolumn{3}{c}{ Escherichia coli } & \multicolumn{3}{c}{ Staphylococcus aureus } \\
\hline Replikasi & 24 jam & 48 jam & $\mathrm{K}(+)$ & 24 jam & 48 jam & $\mathrm{K}(+)$ \\
1 & 8,51 & 7,91 & 6,90 & 9,18 & 8,50 & 7,93 \\
2 & 8,04 & 6,03 & 6,87 & 9,31 & 6,43 & 7,90 \\
3 & 8,81 & 6,38 & 7,10 & 9,48 & 8,54 & 7,78 \\
$\mathrm{X} \pm \mathrm{SD}$ & $8,45 \pm 0,388$ & $6,77 \pm 0,999$ & $6,95 \pm 0,125$ & $9,32 \pm 0,150$ & $7,82 \pm 1,205$ & $7,87 \pm 0,079$ \\
\hline
\end{tabular}

Ket $: \mathrm{X} \pm \mathrm{SD}=$ rata-rata zona bening $(\mathrm{mm}) \pm$ standar deviasi, $\mathrm{K}(+)=$ kontrol positif 


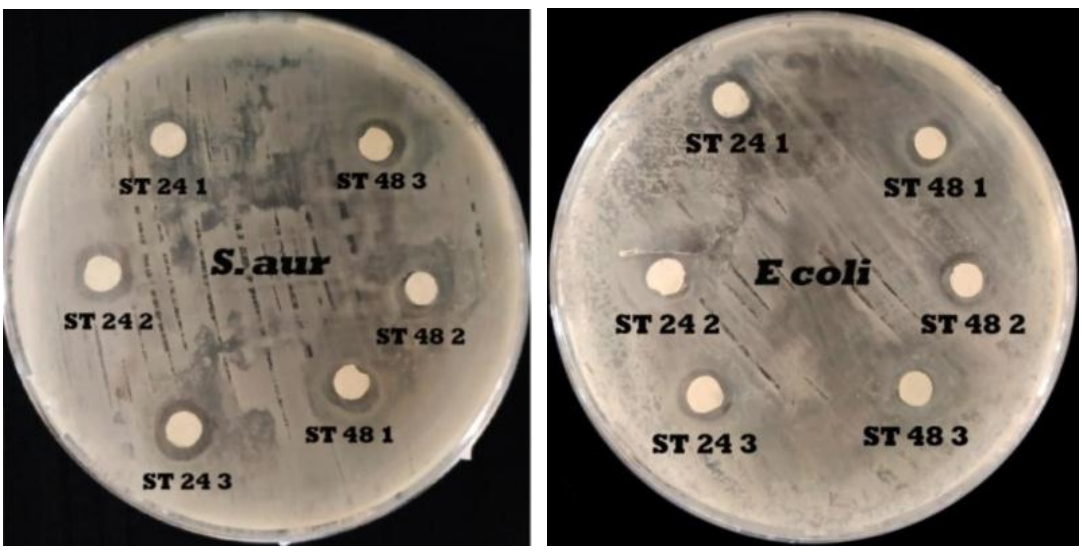

Gambar 1. Hasil uji antibakteri susu fermentasi waktu inkubasi jam ke-24 dan 48 jam terhadap (a) Staphylococcus aureus dan (b) Eschericia coli (Keterangan : ST $24(1,2,3)=3$ replikasi susu fermentasi 24 jam dan ST $48(1,2,3)=3$ replikasi susu fermentasi 48 jam)

\section{Pembahasan}

Hasil aktivitas antibakteri bakteriosin susu fermentasi dapat dilihat pada tabel 1. Susu fermentasi 24 jam menghasilkan zona bening lebih besar dibandingkan dengan susu fermentasi 48 jam. Penelitian Karthikeyan (2013), menyatakan Lactobacillus casei memiliki waktu optimum produksi bakteriosin pada waktu inkubasi 24 jam daripada 48 jam sehingga susu fermentasi 24 jam lebih optimum produksi bakteriosin oleh Lactobacillus casei daripada susu fermentasi 48 jam. $^{15}$

Faktor produksi bakteriosin dipengaruhi oleh waktu fermentasi. Waktu fermentasi yang terlalu lama dapat menyebabkan kekurangan nutrisi bagi bakteri asam laktat sehingga susu fermentasi 24 jam memiliki aktivitas yang lebih besar dibandingkan dengan 48 jam. $^{5}$ Waktu inkubasi yang semakin meningkat menyebabkan $\mathrm{pH}$ pada susu fermentasi semakin asam yang disebabkan oleh terbentuknya asam-asam organik dalam jumlah banyak sehingga aktivitas bakteriosin berkurang. ${ }^{16}$ Selain itu, waktu inkubasi yang terlalu lama, enzim protease akan ter-inaktivasi sehingga dapat mendegradasi bakteriosin yang terbentuk di dalam media. ${ }^{17}$

Hasil uji antibakteri pada susu fermentasi 24 jam dan 48 jam memiliki aktivitas antibakteri yang lebih kuat pada bakteri Staphylococcus aureus dibandingkan dengan bakteri Escherichia coli yang sesuai dengan penelitian oleh Karthikeyan (2013). Bakteri Escherichia coli memiliki lapisan dinding sel yang lebih kuat dan tebal karena mengandung lipid sehingga lebih tahan terhadap senyawa antibakteri daripada bakteri gram positif. ${ }^{18}$ Hasil uji independent T-test, antibakteri susu fermentasi waktu fermentasi 24 dan 48 jam pada bakteri Escherichia coli dan Staphylococcus aureus memiliki nilai taraf signifikansi sebesar $(\mathrm{P}>0,05)$ karena nilai $\mathrm{P}$ sebesar 0,1 sehingga menunjukkan tidak adanya perbedaan signifikan pada zona bening aktivitas antibakteri bakteriosin yang dihasilkan.

\section{Kesimpulan}

Susu fermentasi dengan starter Lactobacillus casei memiliki aktivitas antibakteri bakteriosin yang lebih optimum pada waktu fermentasi 24 jam terhadap Escherichia coli dan Staphylococcus aureus dengan diameter zona hambat sebesar 8,45 mm dan 9,32 $\mathrm{mm}$.

\section{Ucapan Terima Kasih}

Terima kasih atas bantuan kepada seluruh tim mikrobiologi farmasi Universitas Tanjungpura.

\section{Daftar Pustaka}

1. Rahman DH, Tanziha I, dan Usmiati S. Formulasi produk susu fermentasi kering dengan penambahan bakteri probiotik Lactobacillus casei dan Bifidobacterium longum. Jurnal Gizi dan Pangan. 2012;7(1):49-56.

2. Hasruddin dan Husna R. Mini riset mikrobiologi terapan. Yogyakarta; Graha Ilmu: 2014.

3. Andarilla W., Sari R., dan Aprimayanti P. Optimasi aktivitas bakteriosin yang dihasilkan oleh Lactobacillus casei dari sotong kering. Jurnal Pendidikan Informatika dan Sains. 2018;7(2):187-96.

4. Jati AU. Produksi bakteri kasar Lactobacillus plantarum 2C12, 1A15, 1B1, dan 2B2 asal daging sapi serta aktivitas antimikrobanya terhadap bakteri patogen. Skripsi. Bogor; IPB: 2012.

5. Sari NP. Uji aktivitas antibakteri bakteriosin dari 
Lactobacillus brevis, Lactobacillus casei, dan Lactobacillus plantarum terhadap bakteri patogen gram positif. Skripsi. UNTAN: Pontianak; 2018.

6. Ardi F, Pato U, dan Rossi E. Evaluasi mutu susu fermentasi biji nangka dengan variasi susu skim menggunakan bakteri Lactobacillus casei subsp. Casei R-68. Jom Faperta. 2017;4(2).

7. Hudaya A, Radiastuti N, Sukandar D, dan Djajanegara. Uji aktivitas antibakteri ekstrak air bunga kecombrang terhadap bakteri $E$. coli dan $S$. aureus sebagai bahan pangan fungsional. Jurnal Biologi. 2014;7(1):9-15.

8. Angkuna SA, Apridamayanti P, dan Sari R. Penentuan waktu optimum produksi bakteriosin dari Lactobacillus casei terhadap bakteri patogen Staphylococcus aureus dan Escherichia coli. Jurnal Mahasiswa Farmasi Fakultas Kedokteran UNTAN. 2019.

9. Nurdyansyah F, Hasbullah UHA. Optimasi fermentasi asam laktat oleh Lactobacillus casei pada media fermentasi yang disubstitusi tepung kulit pisang. Journal of Biology. 2018;11(1):64-71.

10. Kamara DS, Rachman SD, Pasisca RW, Djajasoepana S, Suprijana O, Idar I, et al. Pembuatan dan aktivitas antibakteri yoghurt hasil fermentasi tiga bakteri (Lactobacillus bulgaricus, Streptococcus thermophilus, Lactobacillus acidophilus). Journal UIN Alauddin. 2016;4(2): 22-7.

11. Lee, W. J., \& Lucey, J. A. Formation and physical properties of yogurt. Asian-Aust. J. Anim. Sci. 2010;23(9):1127-36.

12. Narimo, Sari R, dan Apridamayanti P. Uji aktivitas antibakteri bakteriosin dari Lactobacillus brevis, Lactobacillus casei dan Lactobacillus plantarum terhadap bakteri patogen gram negatif. Jurnal Farmasi Kalbar. 2019.

13. Soelama HJJ, Kepel BJ, Siagian KV. Uji minimum inhibitory concentration (MIC) ekstrak rumput laut (Eucheuma cottonii) sebagai antibakteri terhadap Streptococcus mutans. Jurnal e-GIGI. 2015;3(2): 374-9.

14. Sidabutar, A.R., Feliatra, Andi, D. Uji aktivitas antimikroba bakteriosin dari bakteri probiotik yang diisolasi dari udang windu (Penaeus Monodon Fabricus). Jurnal Online Mahasiswa FAPERIKA. 2015;2(2):1-13.

15. Karthikeyan V, Gnanamoorthy P, Sakthivel A, Bharadhirajan P, Gopalakrishnan A. Isolation, Identification and optimization of bacteriocin production by Lactobacillus casei for their bio prospective applications. Journal Of Pure And Applied Microbiology. 2013;7(3):1-7.

16. Hasan A dan Wikandari PR. Penentuan waktu produksi optimum bakteriosin asal Lactobacillus plantarum B1765 berdasarkan aktivitas penghambatannya terhadap Staphylococcus aureus. UNESA Journal of Chemistry. 2018;7(1):15-20.

17. Elayaraja S, Annamalai N, Mayavu P, Balasubramanian. Production, purification and characterization of bacteriocin from Lactobacillus murinus AU06 and its broad antibacterial spectrum. Asian Pac Journal Trop Biomed. 2014:4(1);305-11.

18. Prissilia N, Sari R, dan Apridamayanti P. Penentuan waktu optimum produksi bakteriosin dari lactobacillus plantarum terhadap bakteri patogen Staphylococcus aureus dan Escherichia coli. Jurnal Mahasiswa Farmasi Fakultas Kedokteran UNTAN. 2019. 